УДК 631.82/84:57.018.:633.34

(C) 2016

Каленська С. М., доктор сільськогосподарських наук, Новицька Н. В., кандидат сільськогосподарських наук, Дэкемесюк О. В., здобувач

Національний університет біоресурсів і природокористування України

\title{
ФОРМУВАННЯ ПЛОЩІ ЛИСТКОВОЇ ПОВЕРХНІ СОЇ ПІД ВПЛИВОМ ІНОКУЛЯЦІї ТА ПІДЖИВЛЕННЯ
}

\section{Рецензент - доктор сільськогосподарських наук О. А. Цюк}

Наведено результати досліджень впливу інокулячії насіння і позакореневого підживлення багатокомпонентними хелатними мікродобривами $і$ колоїдним розчином комплексу наночастинок металів на фоні мінеральних добрив на динаміку формування площі листкової поверхні посівів сортів сої. Польові дослідження проводили на чорноземах типових Лісостепу України на кафедрі рослиннищтва у ВП НУБіП України «Агрономічна дослідна станція». Варіанти досліджень включали інокуляцію насіння бактеріальним препаратом «ХайКот Супер» + «ХайКот Супер Extender», підживлення у фазу бутонізаиії комплексними мікродобривами «ВуксалКомбі Плюс» (2 л/га) $i$ «Росток Бобові» (2 л/га) та запатентованим маточним колоїдним розчином комплексу (Fe, $\mathrm{Mn}, \mathrm{Mo}, \mathrm{Co}$, $\mathrm{Cu}, \mathrm{Zn}, \mathrm{Ag})$ наночасток металів (240 мг/1 л/حa). Встановлено, щуо найбільшу площу листя виявлено в ультрараннього сорту Легенда та ранньостиглого сорту Хорол, яка на варіанті з інокуляиією насіння

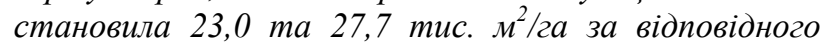

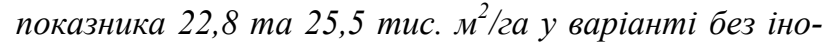
куляції. Застосування комплексу наночасток металів у концентрації 240 мг/л для обприскування посівів сої на початку бутонізації сприяє збільшенню площзі листя у фазі извітіння до 22,9 для ультраранніх та 28,1 тис. $м^{2} / 2 а$ - для ранньостиглих сортів сої. Максима-

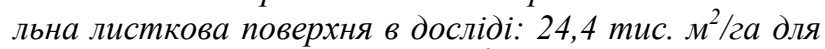
сорту Легенда та 30,9 тис. $\mathrm{M}^{2} / 2 а$ - для сорту Хорол - формувалася в разі поєднання інокуляиії насіння «XайKom Cуnер» + «ХайKom Cуnер Extender» $i$ nозакореневого підживлення комплексним мікродобривом «Росток Бобові».

Ключові слова: Glycine hispida Maxim., сорт, інокуляиія, позакореневе підживлення, мікродобрива, наночастки металів, площа листкової поверхні.

Постановка проблеми. Соя належить до найважливіших білкових та олійних культур, яка забезпечує виробництво корисних для людини харчових продуктів, високопоживних кормів для тварин і є цінною сировиною для переробної промисловості $[1-4,9]$. Важливою умовою формування високих урожаїв сільськогосподарських культур є збільшення продуктивності їх фотосин- тезу, тобто кількості синтезованої органічної речовини на одиницю площі листкової поверхні за добу. Одним 3 основних завдань у досягненні цієї мети $є$ формування посівів 3 найбільш розвиненим листковим апаратом, який тривалий час (максимально) знаходився б у активному стані як на початку, так і наприкінці вегетаційного періоду $[11,18]$. Адже відомо, що добре розвинений фотосинтетичний апарат, оптимальний за об'ємом i динамікою функціонування, є одним із чинників одержання високих і сталих урожаїв сільськогосподарських культур. Він повинен відзначатися високою інтенсивністю та продуктивністю в усі фази росту і розвитку рослин $[10,12]$.

Аналіз основних досліджень і публікацій, у яких започатковано розв'язання проблеми. Найвищі й найкращі за якістю врожаї сільськогосподарських рослин можна отримати в посівах 3 оптимальною за розмірами площею листків, оптимальним ходом іiї формування і структурою [5, 20]. Оптимальний ріст листкової поверхні та формування високого фотосинтетичного потенціалу листя в значній мірі залежать від обгрунтованості технологій вирощування, які забезпечують тривалішу роботу листкового апарату $[8,12]$.

Вважається, що основою, завдяки якій внаслідок фотосинтетичної діяльності створюється врожай сої, є формування оптимальної площі листкової поверхні. Листкова поверхня вловлює сонячну енергію і синтезує органічні сполуки, які йдуть на формування нових органів рослин $\mathrm{i}$ врожаю $[7,12,16]$. Згідно з результатами досліджень проведених у Лісостепу України відомо, що оптимальна площа листової поверхні для сої повинна становити 40-50 тис. $\mathrm{m}^{2} /$ га. Якщо площа листової поверхні менша, то оптико-біологічна структура посіву не оптимізована і тому ФАР використовується не раціонально. Проте й більша площа листової поверхні $є$ небажаною, оскільки в результаті взаємозатінення значна частина листків у нижньому ярусі обпадає, а решта працює не ефективно $[5,17]$.

Численними дослідженнями встановлено, що 


\section{СІЛЬСЬКЕ ГОСПОДАРСТВО. РОСЛИННИЦТВО}

величина та інтенсивність роботи фотосинтетичного листкового апарату сої залежить від генотипу сорту, екологічних умов регіону та агротехнічних заходів по їі вирощуванню $[13,14,20$, 21]. Проте в науковій літературі мало зустрічаються дані щодо особливостей формування площі листової поверхні в посівах залежно від позакореневого підживлення та обробки бактеріальними препаратами в умовах Правобережного Лісостепу України.

Метою дослідження було вивчення впливу інокуляції та позакореневого підживлення багатокомпонентним нанопрепаратом та хелатними мікродобривами на активізацію процесу фотосинтезу, зокрема на формування площі листової поверхні сортів сої на чорноземах типових Лісостепу України.

Завдання дослідження полягало у вивченні потенціалу формування площі листкової поверхні ультра- та ранньостиглими сортами сої за умови проведення інокуляції насіння «ХайКот Супер» + «ХайКот Супер Extender» та позакореневого підживлення мікродобривами «Росток Бобові», «ВуксалКомбі Плюс» та розчином комплексу наночасток металів.

Матеріали і методи досліджень. Польові дослідження проводили у 2013-2015 рр. у стаціонарному досліді кафедри рослинництва на полях ВП «Агрономічна дослідна станція» Національного університету біоресурсів і природокористування України (с. Пшеничне Васильківського району Київської області). Ірунт дослідної ділянки - чорнозем типовий малогумусний грубопилувато-суглинковий. Питома маса твердої фази

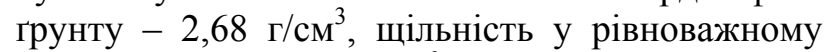

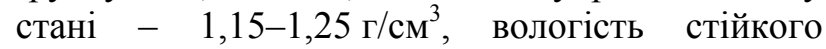
в'янення - 10,9\%, вміст гумусу в шарі 0-20 см 4,60\%, у 25-50 см - 4,22 \%, pН сольової витяжки - 6,9-7,1; ємність поглинання - 30,3-31,4 мг/екв на 100 г грунту.

Агротехніка в досліді загальноприйнята для зони Лісостепу за винятком факторів, які були поставлені на вивчення. Загальна площа елементарної ділянки - $84 \mathrm{~m}^{2}$, облікової - 52,8 м² [6]. Повторність досліду чотириразова. В дослідженнях вивчали ультраранні (80-90 діб) сорти сої: Аннушка (ПП НССФ «Соєвий вік»), Легенда (ННЦ «Інститут землеробства НААН»), Танаїс (ТОВ «Науково-дослідний інститут сої») та ранньостиглі (100-110 діб) сорти: Золотиста (Інститут кормів та сільського господарства Поділля НААН), Десна, Хорол (ТОВ «Науково-дослідний інститут сої»). Сою висівали сівалкою Great plaints 3 міжряддям 15 см при температурі грунту на глибині загортання насіння 10-12 ${ }^{\circ} \mathrm{C}$. Норма висіву сої - 900 тис. насінин на 1 гектар. 3 осені під оранку вносили гранульований суперфосфат $\left(\mathrm{P}_{2} \mathrm{O}_{5}-19 \%\right)$ і калійну сіль $\left(\mathrm{K}_{2} \mathrm{O}-40 \%\right)$ у нормі 60 кг/га д. р. Навесні проводили закриття вологи i вносили аміачну селітру (N $-30 \%)$ у нормі 30 кг/га д.р. Для захисту від бур'янів застосовували грунтовий гербіцид «Харнес» (2,0 л/га), до фази третього трійчастого листка - суміш гербіцидів «Базагран» (2,0 л/га) та «Арамо» (1,5 л/га).

Інокулювали насіння сучасним високоефективним пре-інокулянтом для обробки насіння сої у рідкій формуляції з екстендером, що подовжує строки застосування обробленого насіння «ХайКот Супер» + «ХайКот Супер Extender» (Bradyrhizobium japonicum, штам 532 C) від компанії BASF iз нормою витрати препарату 1,42 л $+1,42$ л на 1 т насіння.

Підживлення багатокомпонентними хелатними комплексними мікродобривами «ВуксалКомбі Плюс» (2 л/га) і «Росток Бобові» (2 л/га) та запатентованим [19] маточним колоїдним розчином комплексу (Fe, $\mathrm{Mn}, \mathrm{Mo}, \mathrm{Co}, \mathrm{Cu}, \mathrm{Zn}, \mathrm{Ag}$ ) наночасток металів (240 мг/1 л/га) проводили на посівах сої на початку бутонізації. Площу листкової поверхні визначали за методикою А. О. Ничипоровича [15].

Результати досліджень. Передусім варто відзначити, що на формування площі листкової поверхні посівів сої різних груп стиглості впливали погодні умови, що сформувалися під час вегетації культури в роки проведення досліджень. Зокрема, 2013 та 2014 pp. за температурними показниками і вологозабезпеченням були більш сприятливими для росту і розвитку рослин сої, ніж 2015 рік. Недостатня кількість атмосферних опадів i нерівномірний їх розподіл протягом вегетації, високі температури і низька відносна вологість повітря в 2015 році були обмежуючим фактором формування площі листкової поверхні посівів сої різних груп стиглості. За рахунок цього у 2015 році площа листкової поверхні досліджуваних сортів сої була нижчою на $0,5-11,5$ тис. $\mathrm{m}^{2} /$ га залежно від варіанту досліду та сортових особливостей, ніж у попередніх 2013 та 2014 роках.

Варто зауважити сортову специфіку у прояві ознаки листкової поверхні (див. табл.). У групи ультраранніх сортів (Аннушка, Легенда, Танаїс) у фазу наливання насіння середня за роки проведення досліджень площа листя не перевищувала 24,024,4 тис. м $^{2} /$ га залежно від інокуляції насіння, позакореневого підживлення та сортових особливостей. Ранньостиглі сорти сої (Десна, Золотиста, Хорол) у фазі наливання насіння формували більшу площу листкової поверхні, яка досягала, залежно

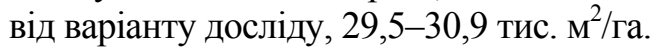




\section{Площа листкової поверхні рослин сої залежно від удобрення та інокуляції насіння} у фазу цвітіння, тис. $\mathrm{M}^{2} / 2 a$

\begin{tabular}{|c|c|c|c|c|c|c|c|c|c|c|c|c|c|c|c|c|}
\hline \multirow{3}{*}{ Сорт } & \multicolumn{16}{|c|}{ Позакореневе підживлення } \\
\hline & \multicolumn{4}{|c|}{ Контроль } & \multicolumn{4}{|c|}{ «ВуксалКомбі Плюс» } & \multicolumn{4}{|c|}{ «Росток Бобові» } & \multicolumn{4}{|c|}{$\begin{array}{c}\text { Комплекс наночасток } \\
\text { металів }\end{array}$} \\
\hline & 2013 & 20 & 2 & $\overline{\mathrm{x}}$ & 2013 & 2014 & 2015 & $\overline{\mathrm{x}}$ & 2013 & 2014 & 2015 & $\overline{\mathrm{x}}$ & 2013 & 2014 & 2015 & $\overline{\mathrm{X}}$ \\
\hline \multicolumn{17}{|c|}{ Ультраранні сорти } \\
\hline \multirow{2}{*}{ Аннушка } &, $1^{1}$ & 22,7 & 1,1 & 22,3 & 23,2 & 23,1 & 22,3 & 22,9 & 23,3 & 23,5 & 22,9 & 23,2 & $\underline{23,2}$ & 2,9 & 21,9 & 22,7 \\
\hline & 23,2 & & 1,8 & 22,7 & 23,5 & 23,4 & & 23,2 & 24,5 & 3,9 & 23,0 &, 8 & 3,5 & 3,1 & 0 & \\
\hline \multirow{2}{*}{ Легенд } & 12 & 2 & 1,9 & 22,8 & 23,1 & 23,3 & $\underline{22,9}$ & 23,1 & 25,2 & 24,1 & 22,3 & 23,9 & 23,9 & 3,5 & 21,1 & 22,8 \\
\hline & 2 & & 2,0 & 23,0 & 24,1 & 24,5 & 22,9 & 23,8 & 25,9 & 24,9 & 22,4 & 24,4 & 24,0 & 3,7 & 21,8 & 2 \\
\hline \multirow{2}{*}{ Танаї } & 21,1 & 20,8 & 0,3 & 20,7 & 23,9 & 24,3 & 21,5 & 23,2 & 23,5 & 23,9 & 22,1 & 23,2 & 23,1 & 3,1 & 0,9 & 22,4 \\
\hline & 1 & & 1,1 & 22,4 & 24,6 & 24,8 & 21,5 & 23,6 & 24,3 & 24,6 & 22,4 & 23,8 & 23,6 & 23,4 & ,4 & 22 \\
\hline \multicolumn{17}{|c|}{ Ранньостиглі сорти } \\
\hline \multirow{2}{*}{ Десн } & $\underline{25,1}$ & 24,3 & $\underline{22,2}$ & $\underline{23,9}$ & 25,9 & 25,4 & 23,1 & 24,8 & 30,1 & $\underline{26,8}$ & $\underline{23,5}$ & $\underline{26,8}$ & 28,5 & $\underline{25,1}$ & 22,4 & 25,3 \\
\hline & 28,4 & 27,5 & 22,8 & 26,2 & 28,9 & 28,4 & 24,5 & 27,3 & 33,5 & 30,2 & 24,9 & 29,5 & 31,5 & 27,9 & 23,1 & 27,5 \\
\hline \multirow{2}{*}{ Золо } & $\underline{24,3}$ & 24,4 & $\underline{22,8}$ & 23,8 & $\underline{25,1}$ & $\underline{24,9}$ & 23,0 & 24,3 & $\underline{29,5}$ & $\underline{30,1}$ & $\underline{22,9}$ & $\underline{27,5}$ & $\underline{27,8}$ & $\underline{26,2}$ & $\underline{22,9}$ & $\underline{25,6}$ \\
\hline & 7,2 & 26,9 & 23,5 & 25,8 & 29,6 & 28,4 & 23,8 & 27,3 & 30,5 & 32,7 & 23,5 & 28,9 & 31,6 & 29,1 & 23,6 & 28,1 \\
\hline \multirow[b]{2}{*}{ Хорол } & $\underline{27,2}$ & $\underline{26,1}$ & $\underline{23,2}$ & 25,5 & 28,7 & 28,3 & 24,1 & $\underline{27,0}$ & 32,1 & $\underline{31,1}$ & $\underline{23,3}$ & $\underline{28,8}$ & $\underline{29,6}$ & 27,9 & 23,5 & 27,0 \\
\hline &, 2 & $2 \varepsilon$ & 4,5 & 27,7 & 32,5 & 30,8 & 25,4 & 29,6 & 36,5 & 31,2 & 24,9 & 30,9 & 30,5 & 28,9 & 24,6 & 28,0 \\
\hline
\end{tabular}

Примітка: ${ }^{1} \mathrm{~B}$ чисельнику - без інокуляції, в знаменнику - інокуляція насіння «ХайКот Супер» + «Extender».

Нами було виявлено, що в групі ультраранніх сортів в середньому за роки проведення досліджень і залежно від варіанту досліду більшу площу листкової поверхні - в межах 22,8-24,4 тис. $\mathrm{m}^{2} /$ га, формував сорт Легенда, меншу - сорт Танаїс - 20,7-24,0 тис. м²/га відповідно. Площа листя сорту Легенда перевищувала площу листя сортів Аннушка i Танаїс на $0,3-2,1$ тис. $\mathrm{m}^{2} /$ га. Найменшу в групі ранньостиглих сортів площу листкової поверхні формував сорт Золотиста $(23,8-$ 28,94 тис. $\mathbf{m}^{2} /$ га), найбільшу - сорт Хорол 25,5-30,9 тис. м²/га відповідно. Посіви сої сорту Десна формували площу листкової поверхні в межах від 23,9 до 29,5 тис. м²/га.

Використання пре-інокулянту у рідкій формуляції з екстендером для обробки насіння активізувало наростання листкової поверхні сортів сої в період цвітіння. Відмічено, що інокуляція насіння «ХайКот Супер» + «ХайКот Супер Extender» дає додатково 0,6-2,5 тис. м $^{2} /$ га приросту площі листової поверхні посівів сої. За рахунок застосування інокуляції асиміляційна поверхня посівів сої зростала від 22,3 (контроль, без інокуляції) до 22,7 (контроль, інокуляція) тис. м²/га у сорті Аннушка, від 22,8 до 23,0 у сорті Легенда і від 20,7 до 22,4 тис. м$^{2} /$ га у сорті Танаїс відповідно. Схожа закономірність спостерігалася і в групі ранньостиглих сортів сої, де за рахунок інокуляції площа листкової поверхні збільшувалася на варіанті контролю від 23,9 до 26,2 тис. $\mathrm{m}^{2} /$ га у сорті Десна, від 23,8 до 25,8 у сорті Золо-

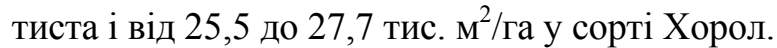

Застосування на початку бутонізації рослин сої позакореневого підживлення багатокомпонентними хелатними комплексними мікродобривами «ВуксалКомбі Плюс» (2 л/га) і «Росток Бобові» (2 л/га) сприяло активному наростанню листкової поверхні рослин досліджуваних сортів сої, та у фазі цвітіння площа листя на цих варіантах досліду і без застосування інокуляції в групі ультраранніх сортів досягала 22,9 і 23,2 тис. $\mathrm{m}^{2} /$ га у сорті Аннушка, 23,1 і 23,9 та 23,2 тис. м²/га - у сортів Легенда й Танаїс. Подібна закономірність відмічена і в групі ранньостиглих сортів. Площа листкової поверхні сорту Десна на варіанті досліду без інокуляції та з внесенням у підживлення мікродобрива «ВуксалКомбі Плюс» (2 л/га) збільшувалася до 24,8 проти 23,9 тис. м²/га на контрольному варіанті; у сорту Золотиста відповідний показник становив 24,3 проти 23,8 тис. $\mathrm{m}^{2} /$ га, у сорті Хорол - 27,0 проти 25,5 тис. м $^{2} /$ га на контрольному варіанті. Обробка вегетуючих рослин сої на початку бутонізації комплексним мікродобривом на хелатній основі «Росток Бобові» (2 л/га) забезпечило зростання листкової поверхні у фазу цвітіння, порівняно з контролем, на 15,5 \% для сорту Золотиста і на 12,1 та 12,9 \% для сортів Десна та Хорол відповідно.

Позитивно на наростання площі листя впливала інокуляція насіння сої «ХайКот Супер» + «ХайКот Супер Extender» у поєднанні з позакореневим підживленням комплексними мікродоб- 


\section{СІЛЬСЬКЕ ГОСПОДАРСТВО. РОСЛИННИЦТВО}

ривами, поскільки мікроелементи, що входять до складу цих мікродобрив, сприяють збільшенню хлорофілу в листках, посиленню асиміляційної діяльності рослин, подовженню роботи листкового апарату. Максимальний в досліді рівень врожайності сої отриманий нами за рахунок поєднання інокуляції насіння та використання для позакореневого підживлення комплексного мікродобрива «Росток Бобові». Зокрема, в групі ультраранніх сортів сої за умови підживлення посівів сої хелатним мікродобривом «Росток Бобові» на ділянках 3 інокуляцією у порівнянні 3 ділянками абсолютного контролю приріст листкової поверхні в середньому за роки проведення досліджень для трьох сортів Аннушка, Легенда й Танаїс становив 6,7, 7,1 та 14,9\% і 23,4, 21,4 та 21,1 \% для трьох сортів ранньостиглої групи Десна, Золотиста та Хорол відповідно. Так, в ультрараннього сорту Легенда застосування комплексного мікродобрива «Росток Бобові» (2 л/га) підвищувало під час цвітіння площу листя до 23,9 тис. $\mathrm{m}^{2} /$ га без інокуляції та до 24,4 тис. м²/га за інокуляції насіння «ХайКот Супер». У ранньостиглого сорту сої Хорол на варіанті досліду із застосуванням мікродобрива «Росток Бобові» (2 л/га) асиміляційна поверхня в період цвітіння досягала

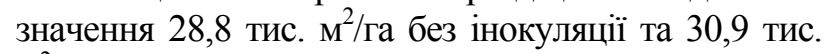
$\mathrm{m}^{2} /$ га за інокуляції насіння «ХайКот Супер» + «ХайКот Супер Extender».

\section{БІБЛІОГРАФІЯ}

1. Бабич A. А. Соя на корм /А. А. Бабич. - М. : Колос, 1974. - 112 с.

2. Бабич A. О. Сучасне виробництво і використання сої : [монографія] / А. О. Бабич. - К. : Урожай, 1993. - 428 с.

3. Бабич A. О. Фотосинтетична діяльність та урожайність насіння сої залежно від строків сівби та системи захисту від хвороб в умовах Лісостепу України / А. О. Бабич, О. М. Венедіктов // Корми і кормовиробництво. - Вінниця, 2004. №53. - С. 83-88.

4. Дерев'янський В. П. Соя / В. П. Дерев'янський. - К. : Укр. ИНТЭИ, 1994. - 216 с.

5. Дәемесюк О. В. Вплив підживлення на динаміку формування площі листкової поверхні посівів сої / О. В. Джемесюк, Н. В. Новицька, I. В. Свистунова // Вісник Житомирського національного агроекологічного університету. - №2 (50), Т. 1. - 2015. - С. 207-212.

6. Доспехов Б. А. Методика полевого опыта (C основами статистической обработки результатов исследований) / Б. А. Доспехов. - М. : Агропромиздат, 1985. - $351 \mathrm{c}$.

7. Ільєнко О. В. Оптимізація прийомів форму-
Використання нанометалів для обприскування посівів сої розчином у концентрації 240 мг/л на початку бутонізації на фоні інокуляції та внесення мінеральних добрив у нормі $\mathrm{N}_{30} \mathrm{P}_{60} \mathrm{~K}_{60}$ сприяло збільшенню площі листкової поверхні ультраранніх сортів у межах від 22,8 до 22,9 тис. м²/га, ранньостиглих сортів - від 27,5 до 28,1 тис. м $^{2} /$ га. У середньому даний варіант досліду забезпечив приріст площі листкової поверхні сортів сої на 0,8-8,7\%.

Висновок. У середньому за роки досліджень відмічено наступне: найбільшу площу листя виявлено в ультрараннього сорту Легенда та ранньостиглого сорту Хорол, яка на варіанті 3 інокуляцією насіння становила 23,0 та 27,7 тис. м²/га за відповідного показника 22,8 та 25,5 тис. м²/га у варіанті без інокуляції. Застосування комплексу наночасток металів в концентрації 240 мг/л для обприскування посівів сої на початку бутонізації сприяє збільшенню площі листя у фазу цвітіння до 22,9 для ультраранніх та 28,1 тис. м²/га для ранньостиглих сортів сої. Максимальна в досліді листкова поверхня 24,4 тис. м $^{2}$ га для сорту Легенда та 30,9 тис. м²/га для сорту Хорол формувалася за поєднання інокуляції насіння «ХайКот Супер» + «ХайКот Супер Extender» та позакореневого підживлення комплексним мікродобривом «Росток Бобові» на фоні добрив у нормі $\mathrm{N}_{30} \mathrm{P}_{60} \mathrm{~K}_{60}$.

вання врожайності сої різних груп стиглості в умовах північної частини степу України : автореф. дис. на здобуття наук. ступеня к.с.-г.н. : спец. 06.01.09 «Рослинництво» / О. В. Ільєнко. Дніпропетровськ, 2008. - 17 с.

8. Каленська С. М. Мінеральне живлення сої / С. М. Каленська, Н. В. Новицька, А. С. Стрихар // Насінництво. - 2009. - № 8. - С. 23-25.

9. Каленська С. М. Стан та перспективи розширення виробництва сої / С. М. Каленська, Н. В. Новицька, А. Є. Стрихар // Науковий вісн. Нац. ун-ту біоресурсів і природокористування України. - 2009. - №141. - С. 133-136.

10. Фотосинтетична діяльність посівів сої на чорноземах типових / [Каленська С. М., Новицька Н. В., Андрієць Д. В., Холодченко Р. М.] // Науковий вісник Національного університету біоресурсів і природокористування України : Серія «Агрономія». - 2011. - Вип. 162, Ч. 1. C. 82-89.

11. Камінський В. Ф. Формування продуктивності сої залежно від агротехнічних заходів в умовах північного Лісостепу України / В. Ф. Камінський, Н. П. Мосьондз // Корми і кормовироб- 
ництво. - 2010. - №67. - С. 45-50.

12. Колісник C.I. Особливості формування фотосинтетичної та насіннєвої продуктивності ранньостиглих сортів сої в умовах правобережного Лісостепу України / С. І. Колісник, О. М. Венедіктов, Д. О. Фабіянський // Корми і кормовиробництво. - 2009. - №64. - С. 55-61.

13. Кочь С. Я. Мінеральні елементи і добрива в живленні рослин / С. Я. Коць, Н. В. Петерсен. К. : Логос, 2005. - $150 \mathrm{c}$.

14. Крамарьов С. Позакореневе підживлення сільськогосподарських культур [Електронний pecypc] / С. Крамарьов // Agrodovidka.info, 01.10. 2012. - Режим доступу : http://agrodovidka.info/ post/1589.

15. Ничипорович А. О. Фізіологія фотосинтезу і продуктивність рослин / А. О. Ничипорович // Фізіологія фотосинтезу. - М., 1982. - С. 7-38.

16. Нідзельський В. А. Спрямування технологічних заходів на стабілізацію урожаїв сої / В. А. Нідзельський, Н. В. Новицька, О. Шутий // Науковий вісник Національного університету біоресурсів і природокористування України : Серія «Агрономія». - К., 2012. - Вип. 176. C. 100-105.

17. Новиџкая Н. В. Урожайность сои в зависимости от элементов технологии на черноземах типичных Лесостепи Украины [Електронный pecypc] / Н. В. Новицкая, А. В. Джемесюк // Вестник Алтайского государственного аграрного университета. - №5 (127). - 2015 - С. 11-16. Режим доступа : http://www.asau.ru/files/vestnik /2015/5/011-016.pdf.

18. Новищька Н. В. Ріст і розвиток сої під впливом наноматеріалів [Електронний ресурс]/ Н. В. Новицька, Р. М. Холодченко : материалы Международной научно-практической Интернет-конференции, 20-27 декабря 2010 г. [«Современные проблемы и пути их решения в науке, транспорте, производстве и образовании' 2010»] ; матеріали доп. - Режим доступу : www.sworld. com.ua.

19. Пат. 38459 України на корисну модель. Маточний колоїдний розчин металів / К. Г. Лопатько, Є. Г. Афтанділянц, О. Л. Тонха, С. М. Каленська ; заявник і власник Національний університет біоресурсів i природокористування України : зареєстр. в Держ. реєстрі патентів України 12.01.2009.

20. Петриченко В. Ф. Агробіологічне обгрунтування і розробка технологічних прийомів підвищення урожайності та якості насіння сої в Лісостепу України / В. Ф. Петриченко : автореф. дис. на здобуття наук. ступеня д.с.-г.н. - К., 1995. - $36 \mathrm{c}$.

21. Ямковий В. Особливості сучасної системи удобрення сої [Електронний ресурс] / В. Ямковий // Пропозиція, 2014. - Режим доступу : http://www.propozitsiya.com/?page $=146 \&$ itemid $=4$ 140. 